\title{
Hubungan antara Stres dengan Emotional Eating pada Mahasiswa Perempuan yang sedang Mengerjakan Skripsi
}

\author{
EGANANDA GRYZELA \& ATIKA DIAN ARIANA* \\ Departemen Psikologi Klinis dan Kesehatan Mental, Fakultas Psikologi Universitas Airlangga
}

\begin{abstract}
ABSTRAK
Penelitian ini menemukan bahwa emosi negative seperti kecemasan, kesedihan atau kesepian akan menimbulkan respon berupa emotional eating. Emotional eating merupakan bentuk coping strategy untuk mengatasi stres dan kecemasan. Penelitian ini bertujuan untuk mengetahui hubungan antara stres dengan emotional eating pada mahasiswa perempuan yang sedang mengerjakan skripsi. Penelitian dilakukan pada 198 mahasiswa perempuan yang sedang mengerjakan skripsi berusia 21-22 tahun. Alat ukur yang digunakan yaitu skala Perceived Stress Scale-10 (PSS-10) dan skala Dutch Eating Behavior Questionnaire (DEBQ). Analisis data dilakukan dengan teknik korelasi Pearson's $r$ dengan bantuan program Jamovi 1.6.6.0 for Windows. Hasil dari penelitian ini menunjukkan adanya korelasi yang signifikan antara stres dan emotional eating $(\mathrm{r}=0,14, \mathrm{p}=0,04)$. Korelasi bersifat positif yang berarti semakin tinggi stres maka semakin tinggi emotional eating pada mahasiswa perempuan yang sedang mengerjakan skripsi.
\end{abstract}

Kata kunci: emotional eating, mahasiswa, perempuan, skripsi, stres

\begin{abstract}
Previous study found that negative emotions such as anxiety, sadness or loneliness will cause a response in the form of emotional eating. Emotional eating is a form of coping strategy to deal with stress and anxiety. This study aimed to determine the relationship between stress and emotional eating in female students who are working on their thesis. This research was conducted on 198 female students aged 21-22 years old who are working on their thesis. The instruments used are the Perceived Stress Scale10 (PSS-10) and the Dutch Eating Behavior Questionnaire (DEBQ). Data was analyzed using Pearson's $r$ correlation technique with Jamovi 1.6.6.0 for Windows. The result shows that there is a positive relationship between stress and emotional eating $(r=0,14, p=0,04)$ which means that the higher the stress, the higher the emotional eating of female students who are working on their thesis.
\end{abstract}

Keywords: emotional eating, female, stress, students, undergraduate thesis

Buletin Penelitian Psikologi dan Kesehatan Mental (BRPKM), 2021, Vol. 1(1), 18-26

*Alamat korespondensi: Fakultas Psikologi Universitas Airlangga, Kampus B Universitas Airlangga Jalan Airlangga 4-6 Surabaya 60286. Surel: atika.ariana@psikologi.unair.ac.id

Naskah ini merupakan naskah dengan akses terbuka dibawah ketentuan the Creative Common Attribution License (CC-BY-4.0) (http://creativecommons.org/licenses/by/4.0), sehingga penggunaan, distribusi, reproduksi dalam media apapun atas artikel ini tidak dibatasi, selama sumber aslinya disitir dengan baik. 


\section{P E N D A H U L U A N}

Makan merupakan salah satu kebutuhan pokok yang secara terus menerus perlu untuk dipenuhi oleh manusia. Berdasarkan hasil penelitian yang dilakukan oleh riset kesehatan dasar atau Riskedas (2013), di Indonesia penduduk yang berumur lebih dari 10 tahun yang mengonsumsi kurang dari 5 porsi buah dan sayur dalam satu hari sebesar 93,5\%. Sedangkan penduduk yang mengonsumsi lebih dari 5 buah dan sayur tiap harinya hanya sebesar 3,3\%. Menurut Yen (dalam Putri, 2015), hal tersebut ditambah dengan adanya perilaku makan yang berlebih (overeating) dan kurangnya aktivitas yang dapat memicu perilaku berisiko yang merupakan penyebab dari penyakit tidak menular (PTM). Pola makan akan menentukan jumlah zat gizi yang diperoleh dan akan memengaruhi pertumbuhan dan perkembangan seorang individu (Elnovriza, Bachtiar, \& Yenrina, 2010). Menurut Elnovriza, Bachtiar dan Yenrina (2010) jumlah makanan yang cukup sesuai dengan kebutuhan akan menyediakan zat gizi yang cukup untuk menjalankan kegiatan fisik. Sehingga, apabila jumlah zat gizi yang diperoleh bagi seorang individu dalam makanan sehari-hari kurang mencukupi maka ada kemungkinan individu tersebut menderita kurang gizi (Elnovriza, Bachtiar, \& Yenrina, 2010). Nyatanya Habriel (dalam Surjadi, 2013) melaporkan terdapat 20,1\% mahasiswa kedokteran di Jakarta mengalami kelebihan berat badan. Penelitian oleh Surjadi (2013) menemukan beberapa faktor yang memengaruhi perilaku makan mahasiswa yaitu kebijakan universitas, keberadaan restoran, keluarga, mahasiswa dan teman sebaya.

Van Strien dan kawan-kawan (dalam Putri, 2015) menjelaskan terdapat tiga aspek perilaku makan yaitu restrained eating, external eating, dan emotional eating. Emotional eating merupakan dorongan makan ketika ada respon dari emosi negatif seperti depresi dan putus asa (Van Strien dkk., 2005). Sejalan dengan ini, Lazarevich, dan kawan-kawan (2015) mengemukakan bahwa emotional eating merupakan respon atas emosi negatif seperti kecemasan, kesedihan atau kesepian. Artinya, emotional eating merupakan coping strategy untuk mengatasi stres dan kecemasan.

Emotional eating sendiri adalah sebagai sesuatu yang bersifat individual, yang dipicu oleh penyebab yang berbeda-beda (Gori \& Kustanti, 2018). Beberapa diantara faktor yang memengaruhi emotional eating adalah stres dan peristiwa yang memicu emosi negatif (Gavin, dalam Putri, 2015; Musyafira, 2018), kebosanan atau perasaan hampa, kebiasaan masa kanak-kanak, dan pengaruh sosial (Gavin, dalam Putri, 2015), kelelahan, kesepian, dan kesedihan (Musyafira, 2018), serta jenis kelamin (Putri, 2015). Perempuan cenderung memiliki dorongan untuk makan yang lebih kuat ketika merasa emosional seperti bosan atau hal lainnya (Putri, 2015). Hal tersebut juga didukung oleh pernyataan dari Hamilton dan Fagot (dalam Lestarianita \& Fakhrurrozi, 2007) yang mengatakan bahwa laki-laki cenderung untuk menggunakan problem focused coping dibandingkan dengan perempuan. Sementara perempuan lebih cenderung menggunakan emotion focused coping dibandingkan dengan laki-laki.

El Ansari (dalam Syarofi \& Muniroh, 2019) menyatakan bahwa stres dapat mengakibatkan perubahan dalam perilaku makan yang tidak sehat serta rendah dalam mengonsumsi sayur dan buah, melewatkan makan seperti sarapan yang dapat memengaruhi berat badan seseorang. Menurut Lubis dan Macth, pada kondisi stres tertentu, beberapa orang dapat kehilangan berat badan akibat penurunan nafsu makan (Syarofi \& Muniroh, 2019; Wijayanti, 2019). Namun, penelitian oleh Harvard Mental Health Latter (dalam Gori \& Kustanti, 2018) menunjukkan sebaliknya yaitu stres menstimulasi otak dan merangsang kelenjar adrenal untuk melepaskan kortisol sehingga terjadi peningkatan nafsu makan dan juga motivasi secara umum (termasuk pula motivasi untuk makan). Menurut McLaughlin (2014) dampak buruk dari emotional eating adalah penurunan fungsi otak, berkurangnya kemampuan beraktivitas, resistensi insulin, kualitas tidur yang memburuk, gangguan pada pencernaan dan mulas, serta masalah suasana hati dan obesitas. 
Mahasiswa yang tengah menulis skripsi menghadapi tantangan tersendiri, seperti menemukan judul yang dapat diterima dosen pembimbing (Alfa, 2014). Tantangan menulis skripsi ini dapat berdampak pada kesehatan mahasiswa, baik fisik maupun psikologis. Penelitian Syarofi dan Muniroh (2019) menemukan adanya stres atau perasaan tertekan dan terbebani yang dirasakan oleh mahasiswa dalam proses pengerjaan skripsi. Lubis dan Nurlaila (dalam Gori \& Kustanti, 2018), mengatakan bahwa kesulitan yang dialami oleh mahasiswa dalam proses pengerjaan skripsi ini membuat mood dan emosi yang mudah berubah-ubah sehingga tidak sedikit pula mahasiswa yang mengalami stres.

Mahasiswa yang menghadapi stressor akademik beresiko mengalami peningkatan konsumsi makanan. Sebuah studi di STIKES Bethesda Yakkum menemukan data bahwa 15 dari 86 (17,4\%) mahasiswa tingkat IV prodi Sarjana Keperawatan pada tahun ajaran 2017-2018 yang sedang dalam tahap proses penyelesaian tugas akhir atau skripsi mengalami peningkatan berat badan karena adanya perubahan pola makan (Gori \& Kustanti, 2018). Selain itu, dalam penelitian yang dilakukan oleh Trimawati dan Wakhid (2018) menunjukkan bahwa terdapat 37 dari 76 (48,7\%) responden yang saat itu sedang dalam proses pengerjaan skripsi menunjukkan perilaku emotional eating. Hal ini juga didukung oleh penelitian pada mahasiswa Gizi FKM Universitas Airlangga yang menemukan bahwa semakin berat stres yang dialami oleh mahasiswa yang menyusun skripsi, maka semakin tinggi kecenderungan mahasiswa menunjukkan perilaku dan pola makan yang berlebih atau emotional eating (Syarofi \& Muniroh, 2019).

Penjelasan yang telah diuraikan sebelumnya membuat peneliti ingin mengetahui lebih lanjut tentang hubungan antara stres dengan emotional eating pada mahasiswa perempuan yang sedang mengerjakan skripsi. Pertanyaan dalam penelitian ini berfokus pada seberapa besar hubungan antara stres dengan emotional eating pada mahasiswa perempuan yang sedang mengerjakan skripsi.

\section{Desain Penelitian}

\section{E T O D E}

Penelitian ini menggunakan pendekatan kuantitatif-survei. Penulis menggunakan pendekatan kuantitatif dengan tujuan menghasilkan data dalam bentuk angka yang didapatkan dari hasil jawaban partisipan melalui survei atau pertanyaan yang diajukan ke sejumlah besar partisipan berupa kuesioner. Pengumpulan data dilakukan dengan menyebarkan kuesioner atau angket secara online melalui Google Form. Kuesioner dibagi menjadi tiga bagian yaitu demografis, skala Perceived Stress Scale-10 untuk mengukur tingkat stres dan bagian skala Dutch Eating Behavior Questionnaire untuk mengukur emotional eating. Uji validitas yang digunakan yaitu internal validity dan validitas isi dengan bantuan professional judgement. Sedangkan pengukuran reliabilitas menggunakan koefisien Alpha Cronbach. Analisis data yang digunakan yaitu korelasi Pearson dengan bantuan program Jamovi 1.6.6.0 for Windows. Analisis data tersebut dipakai dengan tujuan untuk mengetahui hubungan antara stres dengan emotional eating pada mahasiswa perempuan yang sedang mengerjakan skripsi.

\section{Partisipan}

Partisipan dalam penelitian ini perempuan, berusia 21-22 tahun, dan mahasiswa yang sedang mengerjakan skripsi. Teknik sampling yang digunakan adalah purposive sampling, yaitu metode pemilihan partisipan penelitian yang sesuai dengan karakteristik yang diharapkan oleh peneliti (Neuman, 2014). Dalam memperkirakan jumlah sampel yang akan diteliti, penulis menggunakan software $G^{*}$ Power dengan statistical power sebesar 0,80 dan effect size sebesar 0,214 maka diperoleh hasil sampel minimal 133 partisipan. Sebelum mengisi survei, partisipan diminta untuk membaca pernyataan yang diberikan untuk memastikan bahwa partisipan setuju untuk berpartisipasi dalam penelitian ini. 
Penelitian melibatkan 198 partisipan $\left(M_{\text {usia }}=21,2 ; S D_{\text {usia }}=0,40\right)$. Lama pengerjaan skripsi oleh partisipan variatif, yaitu 1 bulan berjumlah 58 orang (29,29\%), 2 bulan sejumlah 47 orang (23,74\%), 3 bulan sejumlah 45 orang (22,73\%), 4 bulan sejumlah 9 orang (4,54\%), 5 bulan sejumlah 11 orang (5,56\%), 6 bulan sejumlah 6 orang (3,03\%), dan yang mengerjakan lebih dari 6 bulan sejumlah 22 orang $(11,11 \%)$.

\section{Pengukuran}

Pengukuran stres dalam penelitian ini menggunakan Perceived Stress Scale 10 (PSS-10) yang disusun Cohen, Kamarck dan Mermelstein dan diterjemahkan oleh Yuniaty (2019). Skala ini terdiri dari 10 aitem dengan 5 kategori pilihan jawaban ( 0 ="tidak pernah", 4="sering") dan mencakup pertanyaan favorable dan unfavorable. Sedangkan pengukuran emotional eating menggunakan Dutch Eating Behavior Questionnaire (DEBQ) yang dikembangkan oleh Van Strien dan diterjemahkan oleh Musyafira (2018). DEBQ dalam penelitian ini digunakan untuk mengukur tiga jenis gangguan makan berlebihan yang terdiri dari external eating, emotional eating, dan restrained eating. Skala ini terdiri dari 33 aitem yang terdiri dari 10 aitem external eating, 13 aitem emotional eating, dan 10 aitem restrained eating. Fokus dalam penelitian ini adalah untuk mengukur perilaku makan berlebihan yaitu emotional eating. Sehingga, aitem yang digunakan oleh penulis hanyalah aitem yang mengukur emotional eating. Skala ini menggunakan 5 kategori pilihan jawaban berupa skala likert (1="tidak pernah", 5="sangat sering").

Validitas yang digunakan yaitu internal validity dan validitas isi (content validity) dengan bantuan professional judge yang dianggap memiliki keahlian sesuai dengan bidang penelitian ini. Pada penelitian ini, validitas alat ukur PSS-10 dan DEBQ mengacu pada hasil penelitian yang dilakukan oleh peneliti sebelumnya terhadap masing-masing alat ukur, yakni Yuniaty (2019) dan Musyafira (2018). Keduanya menggunakan validitas isi dan menguji alat ukur PSS-10 dan DEBQ dengan professional judgement. Sedangkan untuk alat ukur PSS-10 juga didukung oleh internal validity dengan rentang koefisien validitas sebesar 0,460-0,780. Sedangkan reliabilitas yang digunakan berasal dari koefisien Cronbach's alpha. Berdasarkan penelitian yang dilakukan sebelumnya, reliabilitas alat ukur PSS-10 adalah coefficient $\alpha=0,78$ dan reliabilitas untuk alat ukur DEBQ yaitu coefficient $\alpha=0,93$. Jika dilihat dari data yang telah dikumpulkan penulis, hasil analisis reliabilitas skala PSS-10 memiliki koefisien reliabilitas sebesar $\alpha=0,78$ dan skala DEBQ sebesar $\alpha=0,91$.

Pemerolehan skor didapatkan dengan cara dijumlah. Uji asumsi yang dilakukan yaitu uji normalitas untuk mengetahui bahwa data yang didapat berdistribusi normal atau tidak. Uji normalitas dilakukan dengan melihat shapiro wilk yaitu data dikatakan normal apabila hasil diatas 0,05.

\section{Analisis Data}

Analisis data yang dilakukan adalah uji korelasi Pearson untuk melihat hubungan antara tingkat stres dan emotional eating. Selain itu, dilakukan juga uji beda menggunakan ANOVA untuk melihat perbedaan tingkat emotional eating ditinjau dari lama pengerjaan skripsi. Seluruh analisis statistik dilakukan dengan bantuan program Jamovi 1.6.6.0 for Windows.

\section{HAS I L P E N EL I T I AN}

Hasil analisis deskriptif menunjukkan sebagian besar partisipan penelitian mengalami stres kategori sedang, yaitu sebanyak 147 orang $(74,24 \%)$. Sedangkan partisipan penelitian yang mengalami stres kategori ringan sebanyak 9 orang $(4,55 \%)$, dan partisipan yang mengalami stres kategori berat sebanyak 42 orang $(21,21 \%)$. Selain itu, sebagian besar partisipan penelitian mengalami emotional eating kategori sedang, yaitu sebanyak 75 orang (37,88\%). Sedangkan partisipan yang mengalami 
emotional eating kategori sangat rendah sebanyak 14 orang (7,07\%), kategori rendah sebanyak 49 orang $(24,75 \%)$, kategori tinggi sebanyak 48 orang $(24,24 \%)$, dan sangat tinggi sebanyak 12 orang $(6,06 \%)$.

Hasil analisis korelasi diketahui bahwa stres berkorelasi positif dan cenderung lemah dengan emotional eating $(\mathrm{r}(198)=0,142,95 \%$ CI $[0,276 ; 0,002], p=0,047)$. Hasil analisis varians satu jalur (one-way ANOVA $)$ menunjukkan bahwa tidak ada perbedaan tingkat emotional eating $(F(6,191)=1,16 ; p=0,328$; $\eta^{2}=0,035 ; \omega^{2}=0,005$ ) berdasarkan lamanya pengerjaan skripsi.

\section{I S K U S I}

Uji korelasi menunjukkan adanya hubungan yang signifikan antara kedua variabel penelitian sehingga, dapat disimpulkan bahwa Ho ditolak. Namun, kekuatan hubungan yang dihasilkan cenderung lemah. Nilai koefisien korelasi yang positif menunjukkan bahwa semakin tinggi tingkat stres maka semakin tinggi pula emotional eating. Tidak ada perbedaan yang signifikan pada emotional eating ditinjau dari lama pengerjaan skripsi.

Hasil penelitian ini selaras dengan penelitian-penelitian yang ada sebelumnya. Penelitian Syarofi dan Muniroh (2019) menunjukkan bahwa terdapat hubungan yang signifikan antara stres dengan emotional eating dimana semakin berat stres yang dialami maka semakin tinggi kecenderungan menunjukkan perilaku emotional eating. Selain itu, penelitian Wijayanti, Margawati dan Wijayanti (2019) menunjukkan bahwa stres berhubungan dengan perilaku makan emotional over-eating, yang mana semakin tinggi stres maka semakin tinggi pula perilaku emotional over-eating, meskipun keduanya cenderung lemah. Penelitian lainnya yang dilakukan oleh Musyafira (2018) menunjukkan adanya korelasi positif dan sedang antara stres dan emotional eating pada mahasiswa tahun pertama.

Syarofi dan Muniroh (2019) menyatakan bahwa semakin berat stres yang dirasakan maka konsumsi makanan tinggi energi dan lemak juga cenderung semakin tinggi. Hal ini juga dapat terjadi karena kecenderungan dalam melakukan coping yang mengarah kepada konsumsi makanan yang lebih banyak dari biasanya serta makanan yang dikonsumsi adalah makanan berlemak (Syarofi \& Muniroh, 2019). Lazarevich, dkk. (2015) juga menjelaskan bahwa ketika seseorang merasakan emosi negatif seperti kecemasan, kesedihan atau kesepian, akan menimbulkan respon berupa emotional eating. Artinya, emotional eating merupakan bentuk coping strategy untuk mengatasi stres dan kecemasan. Coping strategy sendiri dapat dibagi menjadi dua yaitu problem focused coping dan emotion focused coping. Namun, fokus dalam penelitian ini adalah pada emotion focused coping yang ditunjukkan dengan cara melakukan emotional eating. Emotion focused coping merupakan coping strategy yang berorientasi pada emosi yang merupakan sebuah usaha untuk meredakan atau mengelola stres emosional yang muncul saat individu tersebut berinteraksi dengan lingkungan (Bakhtiar \& Asriani, 2015).

Menurut Folkman dan Lazarus (dalam Widiani, Sismiati, dan Komalasari, 2013) problem focused coping dan emotion focused coping dapat digunakan pada saat yang sama, karena problem focused coping membutuhkan regulasi emosi dan begitu pula sebaliknya untuk emotion focused coping. Selain itu juga emotional focused coping hanya berfungsi sebagai regulator respon emosional yang bersifat sementara waktu (Widiani, Sismiati, \& Komalasari, 2013). Sifatnya yang sementara waktu membuat stres yang awal dirasakan akan kembali lagi bahkan mungkin bisa lebih besar tingkatannya (Widiani, Sismiati, \& Komalasari, 2013).

Hasil dari penelitian ini berbeda dari temuan Wijayanti, Margawati dan Wijayanti (2019) yang menemukan bahwa 23\% subjek mengalami emotional over-eating dimana peningkatan dari nafsu 
makan tersebut terjadi apabila stres yang dialami telah terjadi dalam jangka waktu yang cukup lama atau kronis. Hal ini dapat dilihat dari hasil uji beda yang telah dilakukan dimana tidak ada perbedaan emotional eating ditinjau dari lama pengerjaan skripsi. Korelasi antara stres dan emotional eating yang cenderung lemah serta tidak adanya perbedaan emotional eating ditinjau dari lama pengerjaan skripsi dapat dijelaskan oleh sifat dari emotional focused coping yang sementara waktu. Selain itu, penggunaan emotional focused coping yang dapat dilakukan bersamaan dengan problem focused coping juga dapat menjadi salah satu dari penyebab hubungan antara stres dan emotional eating cenderung lemah. Ada pula penjelasan dari Wijayanti, Margawati dan Wijayanti (2019) yaitu mengenai emotional under-eating yaitu ketika individu yang sedang dalam keadaan stres justru akan mengonsumsi makanan dalam jumlah yang sedikit atau bahkan tidak makan sama sekali.

\section{S I M P U L A N}

Hasil dari penelitian ini menunjukkan adanya hubungan antara stres dan emotional eating. Kekuatan korelasi antara kedua variabel adalah cenderung lemah, sehingga dapat diartikan bahwa stres memberikan dampak yang kecil terhadap emotional eating pada mahasiswa perempuan yang sedang mengerjakan skripsi. Sedangkan arah hubungan antara kedua variabel tersebut yaitu berarah positif yang berarti, semakin meningkat stres maka semakin meningkat pula emotional eating pada seorang individu. Hal ini berlaku juga sebaliknya, semakin menurun stres seorang individu maka semakin menurun pula emotional eating-nya.

Saran bagi mahasiswi yang tengah mengerjakan skripsi yaitu dapat mengontrol dan mengelola diri dalam menanggapi emosi yang bersifat negatif sehingga mampu mengurangi bentuk coping berupa makan berlebihan (emotional eating) yang tentunya memiliki dampak buruk. Mahasiswa perempuan yang sedang mengerjakan skripsi juga dapat menyeimbangkan metode coping yang berupa emotional focused coping dengan problem focused coping. Disarankan pula untuk melakukan kegiatan-kegiatan yang bersifat positif sebagai bentuk strategi untuk meredakan emosi negatif yang dirasakan. Sedangkan bagi penelitian selanjutnya dapat dipertimbangkan faktor-faktor lain sebagai variabel yang memengaruhi emotional eating. Sebaiknya juga dapat melakukan pengambilan data penelitian yang lebih luas agar bisa menggambarkan populasi yang besar.

\section{U CA P A N TERIMAKASI H}

Terima kasih saya ucapkan kepada Allah SWT, keluarga, dan teman-teman yang telah mendukung dan membantu penulis selama proses penelitian. Terima kasih juga saya ucapkan kepada peneliti sebelumnya yang telah memberikan izin untuk pemakaian alat ukur emotional eating dan stres.

\section{DEKLARASI POTENSI TERJADINYAKONFLIK KEPENTINGAN}

Egananda Gryzela tidak bekerja, menjadi konsultan, memiliki saham, atau menerima dana dari perusahaan atau organisasi manapun yang mungkin akan mengambil untung dari diterbitkannya naskah ini. 


\section{PUSTAKA ACUAN}

Alfa, A. (2014). Perilaku copyng mahasiswa Fakultas Dakwah dan Komunikasi dalam mengatasi stres mengerjakan skripsi (tinjauan bimbingan dan konseling islam). Undergraduate (S1) thesis: UIN Walisongo.

Bakhtiar, M. I., \& Asriani. (2015). Effectiveness Strategy of Problem Focused Coping and Emotion Focused Coping in Improving Stress Management Student of SMA Negeri 1 Barru. Guidena, 6982.

Elnovriza, D., Bachtiar, H., \& Yenrina. (2010). Hubungan Pengetahuan dan Asupan Zat Gizi dengan Status Gizi Mahasiswa Asrama Universitas Andalas. Jurnal Kesehatan Masyarakat, 21-26.

Gori, M., \& Kustanti, Y. C. (2018). Studi Kualitatif Perilaku Emotional Eating Mahasiswa Tingkat IV Program Studi Sarjana Keperawatan di STIKES Bethesda Yakkum Yogyakarta. Jurnal Stikes Bethesda, 88-98.

Lazarevich, I., Irigoyen-Camacho, M. E., Del Consuelo Velázquez-Alva, M., \& Salinas-Ávila, J. (2015). Psychometric characteristics of the Eating and Appraisal Due To Emotions and Stress Questionnaire and obesity in Mexican university students. Nutricion Hospitalaria, 31(6), 24372444. https://doi.org/10.3305/nh.2015.31.6.8960.

Lestarianita, P., \& Fakhrurrozi, M. (2007). Pengatasan Stres pada Perawat Pria dan Wanita. Jurnal Psikologi, 47-51.

McLaughlin, A. (2014). Short Term Effect of Bad Eating Habits.

Musyafira, I. D. (2018). Hubungan Stress dan Emotional Eating pada Mahasiswa Tahun Pertama. Surabaya: Universitas Airlangga.

Neuman, W. (2014). Social Research Methods: Qualitative and Quantitative Approaches Seventh Edition. Essex: Pearson Education Limited.

Putri, H. R. (2015). Perbedaan Tingkat Emotional Eating antara Laki-Laki dan Perempuan pada Eerging Adults di Jakarta. Undergraduate thesis: BINUS.

Riskedas. (2013). Riset Kesehatan Dasar 2013. Jakarta: Bakti Husada.

Surjadi, C. (2013). Globalisasi dan Pola Makan Mahasiswa: Studi Kasus di Jakarta. CDK, 416-421.

Syarofi, Z. N., \& Muniroh, L. (2019). Apakah Perilaku dan Asupan Makan Berlebih Berkaitan dengan Stress pada Mahasiswa Gizi yang Menyusun Skripsi?. Media Gizi Indonesia, 38-44.

Trimawati, \& Wakhid, A. (2018). Studi Deskriptif Perilaku Emotional Eating Mahasiswa yang Mengerjakan Skripsi di Universitas Ngudi Waluyo Ungaran. Jurnal SMART Keperawatan Sekolah Tinggi Ilmu Kesehatan (StIKes) Karya Husada Semaran, 52-60.

Van Strien, T. Van, Engels, R. C. M. E., Leeuwe, J. Van, \& Snoek, H. M. (2005). The Stice model of overeating: Tests in clinical and non-clinical samples. Appetite, 45(3), 205-213. https://doi.org/10.1016/i.appet.2005.08.004

Widiani, S., Sismiati, A., \& Komalasari, G. (2013). Hubungan Tingkat Stres dengan Penggunaan Strategi Coping pada Mahasiswa yang sedang Menyusun Skripsi Jurusan BK Angkatan 2008 FIP UNJ. Insight Jurnal, 107-113.

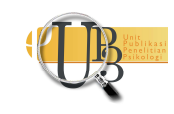


Wijayanti, A., Margawati, A., \& Wijayanti, H. S. (2019). Hubungan Stres, Perilaku Makan, dan Asupan Zat Gizi dengan Status Gizi Pada Mahasiswa Tingkat Akhir. Journal of NutritionCollege, 1-8.

Yuniaty, S. (2019). Pengaruh Perceived Stress dan Religiusitas terhadap Intensi Bunuh Diri pada Dewasa Awal. Surabaya: Universitas Airlangga. 